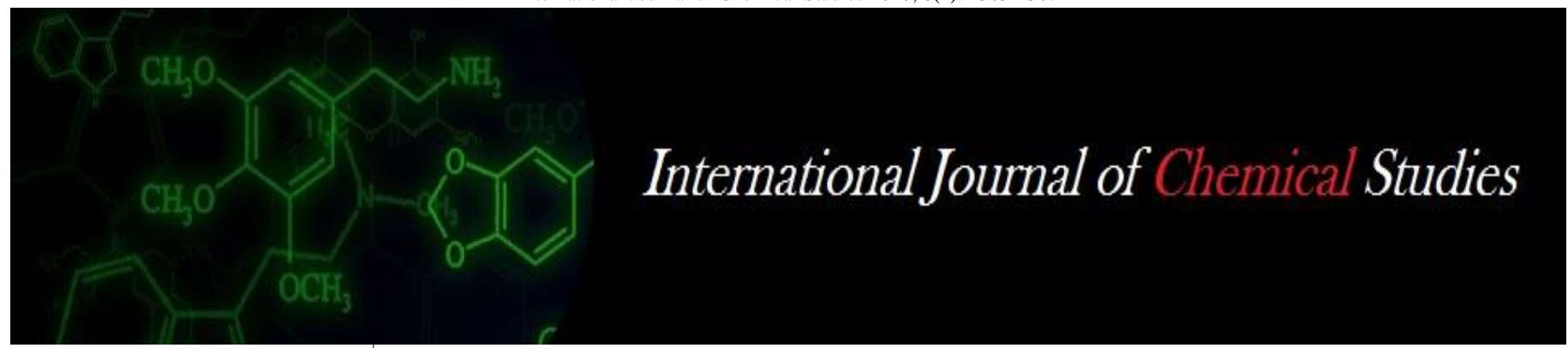

P-ISSN: 2349-8528

E-ISSN: 2321-4902

www.chemijournal.com

IJCS 2020; 8(4): 1565-1567

(C) 2020 IJCS

Received: 13-05-2020

Accepted: 16-06-2020

Ganta Shyam Kumar

Soil Science and Agricultural

Chemistry, Naini Agricultural Institute, Prayagraj, Uttar

Pradesh, India

Tarence Thomas

Soil Science and Agricultural

Chemistry, Naini Agricultural

Institute, Prayagraj, Uttar

Pradesh, India
Corresponding Author: Ganta Shyam Kumar

Soil Science and Agricultural Chemistry, Naini Agricultural Institute, Prayagraj, Uttar Pradesh, India

\section{Effect of different levels of fertilizers and organic matter on soil Physico-chemical properties, growth and yield of baby corn (Zea mays L.) G- 5414 Variety}

\section{Ganta Shyam Kumar and Tarence Thomas}

DOI: https://doi.org/10.22271/chemi.2020.v8.i4o.9834

\begin{abstract}
Organic and inorganic nutrients are important for crop productivity and soil health. Present study investigated the Effect of different levels of fertilizers and organic matter on soil physico-chemical properties, Growth and yield of Baby Corn (zea mays L) G-5414 Variety. Field experiment was conducted at Department of Soil Science and Agricultural Chemistry, Naini Agricultural Institute, Prayagraj - 211007, during kharif 2019 on loamy sand soil. The experiment consisted of 9 treatment viz., T0--Control (No Treatment), T1--NPK 100\% + Organics 0\%, T2--NPK0\% + vermicompost 100\% $10 \mathrm{t}$ ha-1, T3--NPK 0\% + Poultry manure 100\% $10 \mathrm{t}$ ha-1,T4--NPK 75\% + Vermicompost 25\% 82:39:20kg ha1+2.5 t ha-1, T5-NPK 75\%+ Poultry manure 25\% 82:39:20 kg ha-1 +2.5:1 tha-1, T6--NPK 50\% + Vermicompost 50\% 55:26:13 kg ha-1+5t ha- 1 and T7--NPK50\% + Poultry manure 50\%55:36:13 kg ha-1 5t ha1T8-NPK 50\% + Organics 25\% 55:26:13 kg ha-1+2.5:1t ha-1. Conclusively, integration of inorganic fertilizers with organic manures can be used with optimum rates to improve crop productivity on sustainable basis. The results showed that progressive increase in level of N P K and organic fertilizer used from different sources in the experiment, the treatment combination(NPK 50\% + Organics 25\%) significantly increased the physical and chemical analysis parameters i.e. (Bulk density $(\mathrm{Mg} \mathrm{m}-3)$, Particle density (Mg m-3), Pore space (\%), \% of solid space, Specific gravity, Water retaining capacity (\%), Soil pH (1:2), EC (dSm-1), Organic carbon (\%), Available Nitrogen (Kg ha-1), Available Phosphorus (Kg ha-1) and Available Potassium (Kg ha-1)of soil.
\end{abstract}

Keywords: NPK, Vermicompos, poultry manure and soil Physico-chemical properties

\section{Introduction}

Maize (Zea mays L.) is considered as one of the most important cereal crop in the world which serves as a staple food more than any of the other cereal crops. Maize (Zea mays L.) 3rd ranks as a food-grain crop after wheat and rice and it is not only a cereal but also used as a vegetable and fodder crop. Maize was originated from America which was domesticated almost 7000 years ago and it provides nutrients to human and as well as animals, and used as respiration, indole acetic acid (IAA) metabolism, phenol metabolism, and as part of the cell membranes (Parr \& Loughman, 1983; Ahmad et al.,2009). Salicylic acid (SA; 2-hydroxybenzoic acid) is an endogenous growth regulator of phenolic nature, which is normally a source of raw material for the production of oil, protein, starch, food sweeteners, alcoholic beverages and fuel source.

In addition to a huge generation of jobs, cultivation has started to gain momentum in periurban areas late due to its export potential. Being a crop with a limited period (50-60 days), it can be planted and harvested 3-4 times a year. However, a few nations, including Thailand, Indonesia, India, and Brazil, are still limited to production areas. Baby corn has gained popularity recently in Taiwan and India as a vegetable mainly in the states such as Delhi, Uttar Pradesh, Haryana, Maharashtra, Karnataka and Andhra Pradesh. Maize covers a large area of 66 lakh hectares with 133 lakh tones produced and $2015 \mathrm{~kg}$ ha-1 productivity in India. There are no reported data for baby corn production in the United States; nevertheless, the United States is the leading importer of baby corn, mainly from Asian countries, especially from Thailand. United States imports accounted for approximately $140 \%$ of total baby corn exported 
by these countries based upon reports of the United States Department of Agriculture and the Foreign Agricultural Service (Aekatasanawan 2001; Stone et al., 2008).

Synergistic effects of organic manures with inorganic fertilizers accumulate more total nitrogen in soils (Huang et al., 2007) ${ }^{[6]}$, but sole application of farm yard manure (FYM) resulted in increased yield of maize (Anatoliy and Thelen, 2007), higher SOM content (44\%), improved soil porosity $(25 \%)$ and 16 times more water holding capacity (Gangwar et al., 2006) ${ }^{[5]}$. A long term residual effect on soil organic $\mathrm{C}$ and soil $\mathrm{P}$ (about 7 to 8 years) were reported by Kihanda et al., (2006) ${ }^{[7]}$ when organic manure was applied in a semi-arid dryland agriculture. Organic manures also affect the soil biological activity (Araújo and Monteiro, 2006) ${ }^{[3]}$, while enhanced phosphorous $(\mathrm{P})$ availability is also well reported with the application of organic manures in the soil (Toor and Bahl, 1997) ${ }^{[8]}$.

A major challenge for this growing sector is the management of this substantial waste burden, which, if managed correctly, is a valuable resource of nutrients. Vermicomposting is an effective way of doing this. Vermicomposts are organic materials broken down by interactions between microoganisms and earthworms in a mesophilic process, to produce fully stabilized organic soil amendments with low $\mathrm{C}$ : $\mathrm{N}$ ratios (Ramasamy, et al., 2011) Vermicompost has large particulate surface area that provides many micro-sites for the microbial activity and strong retention of nutrients. The nutrients content in vermicompost vary depending on the waste materials that is being used for compost preparation. If the waste materials are heterogeneous one, there will be wide range of nutrients available in the compost.

\section{Materials and Methods Soil Sampling}

The soil of experimental area falls in order of Inceptisol and in experimental plots is alluvial soil in nature. The soil samples randomly collect from five different sites in the experiment plot prior to tillage operation from a depth of $0-15$ $\mathrm{cm}$. The size of the soil sample reduce by conning and quartering the composites soil sample is air dry and pass through a $2 \mathrm{~mm}$ sieve by way of preparing the sample for physical and chemical analysis. The experimental details are given below under different heading:

\section{Design and treatment}

The experiment was carried out in randomized block design with three levels of N P K, three levels of Vermicompost. The treatments were replicated three times and were allocated at random in each replication.

\section{Experimental sites}

The experiment was conducted on the research farm of department of Soil Science and agricultural chemistry, Sam
Higginbottom University of Agriculture, Technology and Sciences, Prayagraj which situated six $\mathrm{km}$ away from Prayagraj city on the right bank of yamuna river, the experimental site is located in the sub - tropical region with $250 \mathrm{~N}$ latitude $81.500 \mathrm{E}$ longitude and $95 \mathrm{MS}$ Laltitude.

Fertilizer application The fertilizers were applied in each plot according to treatment combinations. T0--Control (No Treatment), T1--NPK 100\% + Organics 0\%, T2--NPK0\% + vermicompost $100 \% 10 \mathrm{t}$ ha-1, T3--NPK 0\% + Poultry manure $100 \% 10$ tha-1,T4--NPK 75\%

+ Vermicompost 25\% 82:39:20kg ha1+2.5 t ha-1, T5--NPK $75 \%+$ Poultry manure $25 \%$

82:39:20 kg ha-1 +2.5:1t ha-1,T6--NPK 50\% + Vermicompost $50 \%$ 55:26:13 kg ha-1+5t ha-1 and T7-NPK50\% + Poultry manure 50\% 55:36:13 kg ha-1 5t ha1T8-NPK 50\% + Organics 25\% 55:26:13 kg ha-1+2.5:1t ha-1 was given in equal quantity to each plot which was calculated on the basis of general recommendation for maize as $0 \mathrm{~kg}, 80 \mathrm{~kg}$, $100 \mathrm{~kg}$ ha-1 wa0073 supplied. On the basis of treatment combination the fertilizer used are described in table below.

\section{Results and Discussion}

The observation of all the parameters were recorded during the course of investigation and subjected to statistical analysis for valid inferences. The results and discussion of the effect of $\mathrm{N}$ P K and organic fertilizer on soil physico-chemical properties have been critically analysed and presented in this chapter.

Data presented in table 1 showed that application ofT8(NPK $50 \%$ + Organics 25\% 55:26:13 kg ha-1+2.5:1t ha-1) was significantly enhanced the soil physico-chemical properties. The significantly Bulk density (1.18 Mgm-3),particle density (3.33 Mgm-3), \% of pore space

$(72.22 \%)$, \% of solid space $(47.37 \%)$, Water retaining capacity $(67.57 \%)$, Specific gravity (2.45), Organic carbon (\%) $(0.76 \%)$, Organic matter $(\%)(0.76 \%)$, E.C (dSm-1) (0.24), $\mathrm{pH}$

(1:2) w/v (7.96), Available Nitrogen ( $\mathrm{kg}$ ha-1) (305.98), Phosphorus (kg ha-1) (52.97) and Potassium (kg ha-1) (29.64)of soil physico-chemical analysis were observed with application of (NPK 50\% + Organics 25\% 55:26:13 kg ha1+2.5:1t ha-1). These findings are corroborated with the previousresults in literature (Eghball et al., 2004; Huang et al., 2007; Agbede et al., 2008) ${ }^{[4,6,1]}$. Surface soil organiccarbon buildup probably due to the addition of plant residues, root exudates, plant and root biomassin the surface layer that decreased with increasedsoil depth regardless of the manures applied (Brar et al., 2013). Also the probable reason for recording by Aphal (2005) and Zhang (2008) and Zhang (2008). Further, Singh et al., (2016), Kharub and Chandra (2010), reported by Jackson et al. (1973), Muhr et al. (1965).

Table 1: Effect of different levels of fertilizers and organic matter on soil physico-chemical properties.

\begin{tabular}{|c|c|c|c|c|c|c|c|c|c|c|c|c|c|}
\hline Treatments & \begin{tabular}{|c|}
$\begin{array}{c}\text { Bulk } \\
\text { density } \\
\left(\begin{array}{c}\text { Mgm- } \\
\text { 3) }\end{array}\right.\end{array}$ \\
\end{tabular} & \begin{tabular}{|l} 
Particle \\
density \\
(Mgm- \\
3)
\end{tabular} & $\begin{array}{l}\% \\
\text { pore } \\
\text { ppace }\end{array}$ & $\begin{array}{l}\% \\
\text { solid } \\
\text { space }\end{array}$ & \begin{tabular}{|c|} 
Water \\
retaining \\
capacity \\
$(\%)$
\end{tabular} & $\begin{array}{c}\text { Specific } \\
\text { g } \\
\text { ravity }\end{array}$ & $\begin{array}{c}\text { Organic } \\
\text { carbon } \\
(\%)\end{array}$ & $\begin{array}{c}\text { Organic } \\
\text { Matter } \\
(\%)\end{array}$ & $\begin{array}{c}\text { E.C } \\
(\mathrm{dSm}- \\
\mathbf{1})\end{array}$ & $\begin{array}{c}\text { pH } \\
(1: 2) \\
\text { w/v }\end{array}$ & $\begin{array}{c}\text { Available } \\
\text { Nitrogen (kg } \\
\text { ha-1) }\end{array}$ & $\begin{array}{c}\text { Phosphorus } \\
\text { (kg ha-1) }\end{array}$ & $\underset{\text { (kg ha-1) }}{\text { Potassium }}$ \\
\hline T0 & 1.11 & 2.5 & 55.55 & 44.45 & 56.12 & 2.26 & 0.6 & 0.6 & 0.17 & 7.9 & 231.61 & 20.56 & 112.46 \\
\hline $\mathrm{T} 1$ & 1.1 & 3.33 & 66.66 & 33.33 & 67.57 & 2.41 & 0.37 & 0.76 & 0.2 & 7.8 & 233.67 & 46.65 & 160.96 \\
\hline $\mathrm{T} 2$ & 1.17 & 2.84 & 55.55 & 44.45 & 60 & 2.43 & 0.76 & 0.37 & 0.19 & 7.8 & 257.81 & 48.79 & 142.2 \\
\hline T3 & 1.05 & 2.22 & 52.63 & \begin{tabular}{|l|}
47.37 \\
\end{tabular} & 61.11 & 2.45 & 0.63 & 0.48 & 0.18 & 7.6 & 276.64 & 51.27 & 144.8 \\
\hline $\mathrm{T} 4$ & 1.12 & 2.2 & 55.55 & 44.45 & 56.75 & 2.11 & 0.36 & 0.36 & 0.21 & 7.78 & 277.68 & 49.14 & 156.23 \\
\hline T5 & 1.14 & 2.5 & 55.55 & 44.43 & 55.55 & 2.42 & 0.22 & 0.74 & 0.24 & 7.73 & 277.18 & 51.15 & 164.12 \\
\hline T6 & 1.08 & 2.23 & 72.22 & 22.78 & 66.66 & 2.29 & 0.26 & 0.26 & 0.2 & 7.67 & 280.83 & 52.97 & 166.38 \\
\hline
\end{tabular}




\begin{tabular}{|c|c|c|c|c|c|c|c|c|c|c|c|c|c|}
\hline T7 & 1.04 & 2.86 & 63.16 & 36.84 & 57.89 & 2 & 0.16 & 0.16 & 0.19 & 7.78 & 299.69 & 51.21 & 173.73 \\
\hline T8 & 1.18 & 2.25 & 64.75 & 35.29 & 64.71 & 2.27 & 0.52 & 0.24 & 0.21 & 7.96 & 305.98 & 49.26 & 181.71 \\
\hline F- test & NS & NS & S & S & S & S & S & S & NS & NS & S & S & S \\
\hline S. Ed. $( \pm)$ & 0.494 & 0.777 & 0.27 & 0.494 & 1.71 & 0.04 & 0.09 & 0.054 & 0.309 & 1.283 & 2.43 & 1.35 & 3.334 \\
\hline $\begin{array}{c}\text { C. D. }(\mathrm{P}= \\
\text { 0.05) }\end{array}$ & 1.02 & 1.604 & 0.557 & 1.02 & 3.53 & 0.082 & 0.186 & 0.111 & 0.637 & 2.649 & 5.016 & 2.787 & 9.781 \\
\hline
\end{tabular}

\section{References}

1. Agbede TM, Ojeniyi SO, Adeyemo AJ. Effect of poultry manure on soil physical andchemical properties, growth and grain yield of sorghum in Southwest, Nigeria. American-Eurasian J Sus. Agri. 2008; 2:72-77.

2. Anatoliy GK, Thelen KD. Effect of winter wheat crop residue on no-till corn growth and development. Agron. J. 2007; 99:549-555.

3. Araújo ASF, Monteiro RTR. Microbial biomass and activity in a Brazilian soil plus untreated and composted textile sludge. Chemosphere. 2006; 64:1043-1046.

4. Eghball S, Bardoux G, Benest D, Verdier B, Mariotti A, Abbadie L. Mechanisms of the priming effect in a savannah soil amended with cellulose. Soil Science Society of America Journal. 68:125-131.

5. Gangwar KS, Singh KK, Sharma SK, Tomar OK. Alternative tillage and crop residue management in wheat after rice in sandy loam soils of Indo-Gengetic plains. Soil Till. Res. 2006; 88:242-252.

6. Huang B, Sun WZ, Hao YZ, Hu J, Yang R, Zou Z et al. Temporal and spatial variability of soil organic matter and total nitrogen in an agricultural ecosystem as affected by farming practices. Geoderma. 2007; 139:336-345.

7. Kihanda FM, Warren GP, Micheni AN. Effect of manure application on crop yield and soil chemical properties in a long-term field trial of semi-arid Kenya. Nutr. Cycl. Agroecosys. 2006; 76:341-354.

8. Toor GS, Bahl GS. Effect of solitary and integrated use of poultry manure and fertilizer phosphorous on the dynamics of $\mathrm{P}$ availability in different soils. Bioresource Technol. 1997; 62:25-28. 